\title{
An Analysis of the Relationship between Fiscal Deficits and Selected Macroeconomic Variables in Nigeria, 1970 - 2011
}

\author{
* Umeora Chinweobo Emmanuel
}

\begin{abstract}
This study investigates the relationship that exists between the Government Deficit Spending and selected macroeconomic variables such as Gross Domestic Product (GDP), Exchange Rate, Inflation, Money Supply and Lending Interest Rate. The period covered is 1970 (when the civil war ended) and 2011. Ordinary Least Squares (OLS) technique was adopted to analyze the relationships. The study concludes that Government Deficit Spending (GDS) has positive significant relationship with GDP. Government Deficit Spending also has positive significant relationship with Exchange Rate, Inflation, and Money Supply. Government Deficit has negative significant relationship with Lending Interest Rate and most likely crowd-out the private sector by raising the cost of funds. Deficit spending has been known to have adverse effects on the economy and government is advised to curtail excessive deficit spending. It is recommended that further research is done to establish other variables that are affected by government deficit spending.
\end{abstract}

Keywords: Government Deficit Spending, Procyclical, Crowd-out, Keynesian Demand Economies, Inflationary dynamics, Seigniorage.

\subsection{Background Of The Study}

\section{Introduction}

The relationship between fiscal deficits and macroeconomic variables such as economic growth, inflation, MS, interest rates and exchange rates, among others remain one of the most widely discussed issues among macroeconomists and policy makers in developed and developing countries. Fiscal deficit otherwise referred to as deficit spending occurs when in a fiscal year current expenditure exceeds current expected income (Dalyop, 2010). The public sector plays a dominant role in the economy of any nation and growth in government spending has often resulted in deficits. Persistent government budget deficits and the resultant budgeoning of public debts have assumed serious concerns in developed, transitional and developing countries (Oladipo and Akingbola, 2011).

In Nigeria, the bloating of government bureaucracy, cost of providing critical infrastructures and shortage of revenue generation, among others has over the decades resulted in persistent annual deficits. A run down of government annual expenditure from 1970 (at the end of the Nigeria - Biafra War) to 2011 shows that the government ran annual deficits for 37 years. The few years when the expenditure was surplus are 1971, 1973, 1974, 1979, 1995 and 1996 (Ezeabasili, Mojekwu and Herbert (2012). The development of deficit financing is often traced to adoption of the Keynesian inspired expenditure that Nigeria adopted to motivate economic growth. The consequences of such deficit spending on many macroeconomic variables can not be underestimated (Oladipo and Akinbobola, 2011). Over the years expansionary monetary policy has been pursued together with a rise in private and public consumption and growth of the internal and external debts. All these have acted to exacerbate the annual government deficits. Cebula (1995) cited in Dalyop (2010) argues that government's narrow revenue base vis-a-vis its expenditure, has likely serious effects on its budget balance.

The growth of government deficits after the civil war in 1970 to the introduction of the Structural Adjustment Programme (SAP) in 1986 was attributed partly to post war reconstruction. It was also due partly to the fact that the government exercised a lot of influence over economic activities and fiscal deficits remained a prominent instrument. Although the persistent deficits were perceived to have adverse effects on the macro economy, the various governments felt that the deficits have to continue to stimulate the economy. In 1986, the government introduced SAP with the hope that with restructuring of the economy, there would be reduction in the deficit spending. But this appears not to have been achieved as the deficits continue to escalate on yearly basis. Dalyop (2010) has it that deficit spending of government has posed challenges to the Nigerian economy with regards to its effectiveness and debt accumulation. Paiko (2012) expressed a similar view that excessive and prolonged deficit spending may negate the attainment of macroeconomic stability and distort growth.

Generally, government finances its deficits in three main ways. First the government finances its deficit by printing of money through the Central Bank. This is called 'ways and means' and the revenue from this process is called Seigniorage. Here the government gets money called' High Powered Money. According to Sill (2005) the extent to which governments use seigniorage to finance deficits plays key role in the link between budget deficits and inflation. Secondly the government also uses debt financing. The government can borrow by the Central Bank issuing short term Money Market Instruments such as Treasury Bills and long term bonds. 
Borrowing can also be from abroad consisting of other countries and multilateral institutions such as the IMF and the World Bank. The third source of financing deficit is through drawing from accumulated foreign exchange reserves.

As part of the existence of persistent deficit spending is the issue of corruption which is perceived to inflate public expenditure and exacerbate annual budget deficit (Aliyu and Elijah 2008).

\subsection{Statement Of The Problem Of The Study}

The relationship between government deficit spending and macroeconomic variables such as GDP, Money Supply, Inflation, Exchange Rates etc. represents one of the most widely discussed issues among macroeconomists. Some adopt Keynesian theory of Aggregate Demand and argue that government deficit spending may be necessary especially when the economy is in a recession or depression. Some economists argue that government deficit spending is detrimental to the economy. For example Anyanwu and Oaikhenan (1995) hold the view that government deficit spending will result in increase in economic growth (GDP). However Dalyop (2010) in his study holds a contrary view by saying that government deficit spending has negative effect on GDP. As regards Money Supply and Inflation Onwioduokit (1999) opines that government deficit spending causes inflation. This is contrary to the findings of Omoke and Oruta (2010) whose work concludes that money supply and government deficit do not cause inflation. Sill (2005) holds the same view that money creation by seigniorage does not cause inflation. On the issue of exchange rate, Egwaikhide, Chete and Falokun (1994) in their study concludes that domestic money supply, GDP and exchange rate are relevent in dealing with the causes of inflation in Nigeria. On relationship of government deficit spending and lending interest rate the a priori expectation is that GDS may not crowd-out the private sector unless the deficit financing is excessive. But Obi and Abu (2008) argue that government deficits can out-compete the private sector. Karel (2011) studied government deficit in Czech Republic and said that government deficit spending is bad. Aisen and Hawner (2008) hold the view that increase in budget deficit may not have significant effect in developed countries but may be significant for developing countries but on country specific.

The existence of these differences has inspired this study based on these points. First conclusions from earlier works on government deficit spending on selected macroeconomic variables are conflicting as explained above. Secondly, in the context of the works, most deal on developed countries. But even in the studies done in Nigeria, there are varying results and conclusions. Thirdly, the timeframe of previous studies seen by the researchers in the literature are shorter periods than the period of the present study that spanned 1970-2011 (i.e. 42 years). Even the most current work in the literature seen by the researcher ends in 2006 . This study then can arguably be said to be very current, being five years more current than the last study. Thus the study is justified based on the gaps identified above.

\subsection{Objectives Of The Study}

The main objectives of the study are to find out the effects of the government deficit spending on selected macroeconomic variables. Specifically the study examines:

i. The effect of government deficit spending on Economic Growth proxied by Gross Domestic Product (GDP).

ii. The relationship between government deficit spending and Money Supply.

iii. The relationship between government deficit spending and Inflation.

iv. The relationship between government deficit spending and exchange rates.

v. The effect of government deficit spending on Lending Rates.

\subsection{Significance Of The Study}

The study covers more variables and a longer period (42 years) than any study to the knowledge of the researcher found in the literature. The results of the study will hopefully enlighten the government on ways of finding possible solution to the deficit financing quagmire. Other researchers will find the study rewarding as it will add to the rich collection of works in the literature.

\subsection{Statement Of Hypotheses}

The following Null hypotheses have been proposed based on the objectives:

$\mathrm{H}_{01}$ Government Deficit Spending does not have significant effect on GDP in Nigeria.

$\mathrm{H}_{02}$ Government Deficit Spending does not have significant effect on Money Supply in Nigeria.

$\mathrm{H}_{03}$ Government Deficit Spending does not have significant effect on Inflation in Nigeria.

$\mathrm{H}_{04}$ Government Deficit Spending does not have significant effect on exchange rates in Nigeria.

$\mathrm{H}_{05}$ Government Deficit Spending does not have significant effect on Lending Interest rates in Nigeria. 


\subsection{Scope Of The Study}

The study is limited to the effects of Federal Government deficit spending on five selected macroeconomic variables namely GDP, Inflation, Money Supply, Exchange Rates and Lending Interest Rates. The list is not exhaustive but these are considered important variables in the economy. The period is limited to 1970 when the civil war ended and 2011. Data are time series for the variables collected principally from CBN Statistical Bulletin. Government Deficit Spending (GDS) is considered as the dependent variables while GDP, Inflation, Money Supply, Exchange Rates and Lending Interest Rates are independent variables.

\subsection{Plan Of The Study}

The paper is arranged in sections, Section 1 is on introduction discussed so far. Section 2 is on review of literature. Section 3 is on presentation, analysis and interpretation of data while section 5 summarizes and concludes the work with recommendation.

\section{Review Of Related Literature}

Fiscal deficits or Government Deficit Spending is related to how it is financed. Anyanwu (1997) states that these are some of the ways that deficit financing can be stated:-

Public Investment + Private Investment $=$ Public Savings +

Private Savings + Foreign Savings --------------- (1)

Or Public Investment + Public Savings $=$ Private Savings -

Private Is + Foreign Savings and

Public Deficit $=$ Private Surplus + Current Account Balance-

\section{1 Theoretical Foundations}

Discussions about the justification for government deficit spending became more accentuated during the Great Depression of the 1930s. Keynes came up with Aggregate Demand theory (Oladipo and Akinbobola, 2011). The theory states that $\mathrm{Y}=\mathrm{C}+\mathrm{I}+\mathrm{G}+(\mathrm{X}-\mathrm{M})$ where $\mathrm{Y}=$ National Income proxied by GDP, $\mathrm{C}=$ Private consumption of Households, $\mathrm{I}=$ Private Investment of the business sector, $\mathrm{G}=$ Government consumption, $\mathrm{X}$ and $\mathrm{M}$ stand for Exports and Imports respectively. Assuming Aggregate Demand is represented by A, then A = C + I $+\mathrm{G} \ldots \ldots \ldots \ldots \ldots$. (3). That means that equation (3) can be written as $\mathrm{Y}-\mathrm{A}=\mathrm{X}-\mathrm{M}$............. (4) Which reflects the behavior of the external sector. The implication is that external imbalances always trigger a series of developments in the economy, which is this case is budget deficit. Any attempt to restore the imbalance includes an effort to align revenue with expenditure. In order to have the disposable Income, tax and international reserves (assumed at fixed exchange rate) are introduced into the national income identity. Then we can state equation (3) as $\mathrm{Y}+\mathrm{R}-\mathrm{T}=(+\mathrm{I}+\mathrm{G}-\mathrm{T})+(\mathrm{R}+\mathrm{X}-\mathrm{M}) \ldots \ldots \ldots \ldots \ldots(5)$. In the savings function below $\mathrm{S}$ (savings) is Disposable Income Less private consumption so that we have $\mathrm{S}=\mathrm{Y}+\mathrm{R}-\mathrm{T}-\mathrm{C}$, and the private absorption is illustrated by $(\mathrm{C}+\mathrm{I}),(\mathrm{G}-\mathrm{T})$ is for Budget Deficit while the Current Account Balance $(\mathrm{CAB})$ is represented by $(\mathrm{R}+\mathrm{X}-\mathrm{M})$, $\mathrm{R}$ represents international transfer receipts and $\mathrm{T}$ stands for Taxes. Substituting for $\mathrm{S}$ and $\mathrm{CAB}$ we have $(\mathrm{S}-\mathrm{I})+(\mathrm{T}-\mathrm{G})=(\mathrm{R}+\mathrm{X}-\mathrm{M})$

\subsection{Review Of Empirical Works}

Karel (2011) writing on the Czech Republic economy, said that many developing (and possibly some transitional) economies experience high deficit spending on the part of governments. These deficits spending have caused many macroeconomic problems for these countries. Among the problems are high level of inflation, highly indebted economies (high domestic and external debts), Current Account deficits (disequilibrium in external balance of foreign trade) and retarded economic growth. He however opined that macroeconomic problems and instability depend on how the deficits are financed. Deficit spending can be financed by selling of instruments such as Treasury Bills and Bonds. The more the government wants to finance its deficits, the less will remain for the private sector. This gives rise to the crowding out of the private sector which is the real sector. The government may finance its deficits from external borrowing which over time will worsen the balance of payments position, increase foreign debt with repayment problems. It will also lead to depletion of external reserves and often results in foreign currency crisis leading to World Bank and IMF coming in to force down unpalatable policies on the nation. Nigeria experienced this for decades up to 2005 when it exited the debt holes of Paris Club and London Club. Printing of Paper money called 'ways and means' in Nigeria has been believed to cause high level of inflation.

\subsection{Government Deficit Spending And Economic Growth In Nigeria}

Kustepeli (2011) studied the effect of nominal government deficits on economic growth (GDP) in Turkey. He made extensive study of literature such as Cebula (1995), Ludvigson (1996), Ahking and Miller (1985) among others whose studies showed that when government deficits are financed by monetary expansion, 
the result is usually inflation. He added that high inflation rate has adverse effect on the economy and results in steady fall in G.D.P. Having accepted the results of the literature he reviewed, he carried out his own tests using co-integration and causality tests. He came to the same conclusion that when sustained governments deficit spending is financed by increase in the monetary base, inflation becomes an undeniable outcome which for prolonged periods adversely affects economic activities and therefore GDP. His study emphasized on deficits financed by increased monetization (ways and means) and did not talk about other factors.

Back here in Nigeria, a number of studies have been done to determine the effects of prolonged government deficit spending on the economic growth. Dalyop (2010) did his study to determine the effects of fiscal deficits and the growth of domestic output in Nigeria. His study is preceded by extensive review of literature. For example, he referred to Akor (2001) who observed that government expenditures grew large as bureaucracy grew. But when there was glut in the crude oil market, revenues declined but government was reluctant in reducing the bloated expenditures that had resulted during the oil boom. Government then resorted to fiscal deficits so as to continue its deficit spending. Dalyop (2010) explains that fiscal deficits occur when government expenditures exceed revenues and have become a recurring feature of public sector financing in Nigeria. However, Keynesian demand side economics justifies deficit financing by governments to reflate an economy that is in a recession or depression (Anyanwu and Oaikhenan (1995) and Ogboru (2006). Dalyop (2010) recounting Ashfa (2007) and Neaime (2008) noted that fiscal deficits may be caused by inadequate collection of taxes and heavy government expenditures in infrastructure. Dalyop's study stated that most government's deficit spending is financed by monetization. Using time series data for the period 1982-2008, he ran a linear regression analysis to show that government's deficit spending has a negative though insignificant impact on economic growth. According to him deficit spending has resulted in heavy borrowing which in turn has given rise to debt burden and its attendant problems. Aliyu and Elijah (2008) add that the excessive government deficit spending has been exacerbated by corruption which tends to inflate public expenditure.

Ezeabasili and Ioraver (2012) in a study on Economic Growth and Fiscal Deficits in Nigeria opine that fiscal deficit affects growth negatively. They advised government to reduce money creation.

\subsection{Government Deficit Spending, Money Supply And Inflation In Nigeria}

Omoke and Orunta (2010) studied Budget Deficits, Money Supply and Inflation in Nigeria. Using inflation as independent variable and budget deficit and Money supply as dependent variables and with the application of $\mathrm{ADF}$ and P-P techniques to test for unit root, they concluded that there is no long term relationship between fiscal deficits, money supply and inflation in Nigeria.

Onwiodukit (1999) studied fiscal deficits and inflationary dynamics in Nigeria. Using time series data from 1970-1994, he wanted to ascertain the impact of fiscal deficits (deficit spending of government) on inflation as well as impact of inflation on deficits spending. In other words he wanted to establish whether it is deficit spending that causes inflation or the other way round. Using Granger Causality test, his study says that fiscal deficits cause inflation. He recommended that government should not only control deficit spending but also the mode of financing the deficits.

Olusoji and Oderinde (2011) in their study of fiscal deficit and inflation Trend in Nigeria, like Onwioduokit (1999), wanted to find out whether deficit spending causes inflation or is it inflation that causes deficit spending. They used what they called more robust Toda-Yamama to Granger non-causality test. Their study did not establish any clear evidence of causality relationship between fiscal deficit and inflation in Nigeria for the period of study, 1970-2006. Their finding is somewhat close to the finding of Onwioduokit (1999). The findings indicate a causality link between deficit spending and inflation but not from inflation to deficit spending. Olusoji and Oderinde (2011) also reported the work of Folorunso and Abiola (2000) whose study also established a significant relationship between fiscal deficits and inflation in Nigeria. Ezeabasili, Mojekwu and Herbert (2012) made empirical study of fiscal deficits and inflation in Nigeria, using Co-integration and Ordinary Least Squares (OLS) techniques. Their results reveal a positive but insignificant relationship between inflation and fiscal deficits in Nigeria. They also reported a positive long run relationship between money supply and inflation suggesting that money supply is procyclical and tends to grow at a faster rate than inflation rate.

\subsection{Government Deficit Spending And Lending Interest Rate In Nigeria}

Aisen and Hauner (2008) studied the effects of fiscal deficits and interest rates in both developed and developing countries. They drew three main conclusions from their study. First, they opined that there is a highly significant positive effect of deficit spending on interest rate; secondly the effect varies from country to country. The effects are large and more robust in the emerging markets than in advanced economies. Thirdly the effect of fiscal deficits on interest rates depends on interaction terms and is significant only under several conditions: when deficit spending is high, when they are financed domestically; when they interact with domestic debt and when trade openness is low. Moreover, the effect is large when interest rates are more liberalized and when the domestic financial sector is less developed, they added. 
Obi and Abu (2009) did a similar study to establish if fiscal deficits raise interest rate in Nigeria. Their results indicate that fiscal deficits and government debt have positive impact on interest rates. They opined that deficits financing leads to huge debt stock and tends to crowd-out private sector investment and raise interest rates. The outcome is fall in productivity and GDP.

Ezeabasili and Mojekwu (2011) carried out a study of fiscal deficits and interest rates in Nigeria. The results are that fiscal deficits and interest rates are positive and statistically significant. The indications are that large deficits cause high interest rates. Also Money Supply has an inverse relationship with interests in Nigeria and there exists a positive and significant relationship between inflation and interest rates.

\subsection{Government Deficit Spending And Exchange Rates In Nigeria}

Egwaikhide et al (1994) did a research on exchange rate depreciation, fiscal deficits and inflation in Nigeria. They used two stage models in their work. First, they used a structural model of co-integration and Error Correction model. Secondly they conducted a simulation experiment. Both models were to establish the impact of exchange rate movements on general price level (inflation) and fiscal deficits. Their study which spanned the period 1970-1989, showed that domestic money supply, real GDP, and exchange rate are important in dealing with causes of inflation in Nigeria. More specifically on the simulation experiment, they discovered that exchange rate depreciation significantly affects both revenue and expenditure sides of both revenues and expenditures in Nigeria and tends to enlarge the deficit spending over time.

Odusola and Akinlo (2001) also carried out a study of inflation and exchange on output in developing countries with Nigeria as a case study. The results of their study were mixed. According to them the impulse response functions exerted an expansionary impact on exchange rate depreciation on output in medium and long term. Contractionary impact was the case in the short run. Evidence from VAR models suggests the impacts of interest rate and inflation on output is negative.

Thus in concluding the review of literature, it has become obvious that previous studies touched government deficit spending on disaggregated variables such as effects on inflation, economic growth, exchange rates. This study aims at taking more variables and a longer period. To the knowledge of the researcher, these gaps exist in the literature.

\subsection{Research Design}

\section{Research Methodology Of The Study}

The study adopted ex-post facto research design to investigate the effects of government deficit spending on selected macroeconomic variables in Nigeria. The data are secondary data obtained from various issues of CBN Statistic Bulletin. Using Ordinary Least Squares (OLS) techniques, the data are analyzed for the period of 42 years $(1970-2011)$

Table I: Data On Macroeconomic Variables Used For The Study

\begin{tabular}{|c|c|c|c|c|c|c|}
\hline Years & $\begin{array}{l}\text { GDP at } \\
\text { Market Price } \\
\text { N Million }\end{array}$ & $\begin{array}{l}\text { Nominal } \\
\text { Exchange Rate } \\
(\text { EXR) }\end{array}$ & $\begin{array}{ll}\text { Inflation } & \text { Rate } \\
\text { (INFL) } & \end{array}$ & $\begin{array}{l}\text { Government Deficit } \\
\text { Spending } \\
\text { N Million }\end{array}$ & $\begin{array}{ll}\text { (MS) } & \text { Money } \\
\text { Supply } & \\
\text { N Million } & \end{array}$ & $\begin{array}{l}\text { Lending Int. } \\
\text { (LIR) Rate } \%\end{array}$ \\
\hline 1970 & 5281.10 & 0.17 & 13.76 & -455.10 & 789.56 & 8.00 \\
\hline 1971 & 6650.90 & 0.71 & 16.00 & 171.60 & 971.93 & 10.00 \\
\hline 1972 & 7187.50 & 0.66 & 3.46 & -58.80 & 1055.82 & 10.00 \\
\hline 1973 & 8630.50 & 0.66 & 5.40 & 166.10 & 1265.99 & 10.00 \\
\hline 1974 & 18823.10 & 0.63 & 12.67 & 1796.40 & 1753.73 & 10.00 \\
\hline 1975 & 21475.24 & 0.62 & 33.96 & 427.90 & 3031.33 & 9.00 \\
\hline 1976 & 26655.78 & 0.63 & 24.30 & -1.90 .80 & 4510.55 & 10.00 \\
\hline 1977 & 31520.34 & 0.65 & 15.09 & -781.40 & 6147.00 & 6.00 \\
\hline 1978 & 34540.10 & 0.61 & 21.71 & -2821.90 & 7392.76 & 11.00 \\
\hline 1979 & 41974.70 & 0.60 & 11.71 & 1461.70 & 9158.80 & 11.00 \\
\hline 1980 & 49632.32 & 0.55 & 9.97 & -1975.20 & 11856.60 & 9.50 \\
\hline 1981 & 47619.66 & 0.61 & 20.81 & -3902.10 & 14471.17 & 10.00 \\
\hline 1982 & 49069.28 & 0.67 & 7.70 & -6104.10 & 15786.74 & 11.75 \\
\hline 1983 & 53107.38 & 0.72 & 23.21 & 3364.50 & 17687.93 & 11.50 \\
\hline 1984 & 59622.53 & 0.76 & 17.82 & -2660.40 & 20105.94 & 13.00 \\
\hline 1985 & 67908.55 & 089 & 7.44 & -30399.70 & 22299.24 & 11.75 \\
\hline 1986 & $69,147.00$ & 2.0206 & 5.4 & $-8,254.30$ & $27,389.80$ & 10.5 \\
\hline 1987 & $105,222.80$ & 4.0179 & 10.2 & $-5,889.70$ & $33,667.40$ & 17.5 \\
\hline 1988 & $139,085.30$ & 4.5367 & 56.0 & $-12,160.90$ & $45,446.90$ & 16.5 \\
\hline 1989 & $216,797.50$ & 7.3916 & 50.5 & $-15,134.70$ & $47,055.00$ & 26.8 \\
\hline 1990 & $267,550.00$ & 8.0378 & 7.5 & $-22,116.10$ & $68,662.50$ & 25.5 \\
\hline 1991 & $312,139.70$ & 9.9095 & 12.7 & $-35,755.20$ & $87,499.80$ & 20.01 \\
\hline 1992 & $532,613.80$ & 17.2984 & 44.8 & $-39,532.50$ & $129,085.50$ & 29.8 \\
\hline 1993 & $683,896.80$ & 22.0511 & 57.2 & $-107,735.30$ & $198,479.20$ & 18.32 \\
\hline 1994 & $899,863.20$ & 21.8861 & 57.0 & $-70,270.60$ & 266.944 .90 & 21 \\
\hline
\end{tabular}




\begin{tabular}{|l|l|l|l|l|l|l|}
\hline 1995 & $1,933,211.60$ & 21.8861 & 72.8 & -1000.00 & $318,763.50$ & 20.18 \\
\hline 1996 & $2,702,719.60$ & 21.8861 & 29.3 & $-32,049.40$ & $370,333.50$ & 19.74 \\
\hline 1997 & $2,801,972.60$ & 21.8861 & 10.7 & $-5,000.00$ & $429,731.30$ & 13.54 \\
\hline 1998 & $2,708,430.90$ & 21.8861 & 7.9 & $-133,389.30$ & $525,637.80$ & 18.29 \\
\hline 1999 & $3,194,015.00$ & 92.6934 & 6.6 & $-285,104.70$ & $699,733.70$ & 21.32 \\
\hline 2001 & $4,582,127.30$ & 102,1052 & 6.9 & $-103,777.30$ & $1,315,869.10$ & 18.29 \\
\hline 2002 & $6,912,381.30$ & 120.9702 & 12.9 & $-301,401.70$ & $1,599,494.60$ & 24.4 \\
\hline 2003 & $8,487,031.60$ & 129.3565 & 14.0 & $-202,724.70$ & $1,985,191.80$ & 20.48 \\
\hline 2004 & $11,411,066.90$ & 133.5004 & 15.0 & $-172,601.30$ & $2,263,587.90$ & 19.15 \\
\hline 2005 & $14,572,239.10$ & 132.1470 & 17.8 & $-161,406.30$ & $2,814,846.10$ & 17.85 \\
\hline 2006 & $18,564,594.70$ & 128.6516 & 8.2 & $-101,397.50$ & $4,027,901.70$ \\
\hline 2007 & $20,657,317.70$ & 125.8331 & 5.4 & $-11,723.50$ & $5,809,826.70$ & 17.3 \\
\hline 2008 & $24,296,329.30$ & 118.5669 & 11.6 & $-47,378.50$ & $9,166,835.30$ & 16.94 \\
\hline 2009 & $24,794,238.70$ & 148.9017 & 12.4 & $-810,008.46$ & $10,767,377.80$ & 15.14 \\
\hline 2010 & $29,205,783.00$ & 150.2980 & 10.9 & $-1,105,439.78$ & $11,034,940.93$ & 17.36 \\
\hline 2011 & $37,543,654.70$ & 155.50 & 10.8 & $-1,354,388.31$ & $11,300,504.06$ \\
\hline
\end{tabular}

SOURCE: CBN STATISTICAL BULLETIN, VARIOUS ISSUES

\subsection{Model Specification}

In the light of the objectives and hypotheses raised in chapter one, a model is specified to examine the relationship between government deficit spending and the selected macroeconomic variables namely GDP, Money Supply, Inflation, Exchange Rate and Lending Interest Rate. The relationship is put in a model as a function below.

GDS $=f(G D P$, MS, INFL, EXR and LIR $)$

This can be stated as an econometric equation thus:

LnGDS $=\mathrm{a}_{0}+\mathrm{a}_{1} \mathrm{LnGDP}_{\mathrm{t}-1}+\mathrm{a}_{2} \mathrm{EXR}+\mathrm{a}_{3} \mathrm{INFL}_{\mathrm{t}}+\mathrm{a}_{4} \mathrm{LnMS}_{\mathrm{t}}+\mathrm{a}_{5} \mathrm{LIR}_{\mathrm{t}}+\mathrm{e}$

Where

GDS $=$ Government Deficit Spending

$\mathrm{LnGDP}_{\mathrm{t}-1}=$ one year lag of natural log of GDP at current market prices.

EXR $=$ Official nominal Exchanger Rate of Naira/US \$

$\mathrm{INFL}=$ Inflation Rate

MS $=$ Broad Money Supply $\left(\mathrm{M}_{2}\right)$

LIR $=$ Lending Interest Rate

$a_{0}$ is the constant while $a_{1}, a_{2}, a_{3}, a_{4}$, and $a_{5}$ are the coefficients of the explanatory variables, e is the stochastic error term while $\mathrm{Ln}$ is natural log used to express the variables in ratio from.

\subsection{Estimation Techniques}

The study employed Ordinary Least Squares (OLS) technique for the analysis. The coefficient of determination $\left(\mathrm{R}^{2}\right)$, F-test, $\mathrm{t}$-test, beta and Durbin-Watson are used in the interpretation of the result.

The SPSS 17 is used to show regress data for Government Deficit Spending (dependent variable) against the explanatory variables - GDP, Exchange Rate, Inflation, Money Supply and Lending Interest Rate independent variables. The decision Rule for the tests of the hypotheses is to reject the Null hypotheses at $5 \%$ level of significance. The coefficient of determination $\left(\mathrm{R}^{2}\right)$ measures the explanatory power of the independent variables on the independent variable. F-test measures the overall significance of the tests. Student's t-test measures the individual significance of the estimated independent variables. The beta (the standardized coefficient) is also used to measure the individual contribution of the variables to variation in the dependent variable. Durbin-Watson (DW) statistics test for auto correlation in the regression.

\subsection{Presentation Of Results}

\section{Presentation And Analysis Of Results}

The results of the analysis of data are summarized in tables 2, 3 and 4 presented below:

Table 2: Model Summary ${ }^{\mathrm{b}}$

\begin{tabular}{|c|c|c|c|c|c|}
\hline Model & $\mathbf{R}$ & r-squared $\left.\mathbf{( R}^{\mathbf{2}}\right)$ & Adjusted $\mathbf{R}^{\mathbf{2}}$ & Std. error of the estimate & Durbin-Watson \\
\hline 1 & $.659^{\mathrm{a}}$ & .434 & .354 & 3.69915 & 2.061 \\
\hline
\end{tabular}

a. Predictors: (Constant), LIR, INFL, EXR, MS, Lags (GDP,1)

b. Dependent variable: GDS

Table 3: ANOVA ${ }^{\mathrm{b}}$

\begin{tabular}{|c|c|c|c|c|c|}
\hline Model & Sum of square & Df & Mean square & F & Sig. \\
\hline $\begin{array}{c}1 \text { regression } \\
\text { Residual }\end{array}$ & 367.908 & 5 & 73.582 & $.001^{\mathbf{a}}$ \\
\hline & 478.930 & 35 & 13.684 & & \\
\hline Total & 846.839 & 40 & & & \\
\hline
\end{tabular}


a. Predictors: (Constant), LIR, INFL, EXR, MS, Lags (GDP,1)

b. Dependent variable: GDS

Table 4: Coefficients

\begin{tabular}{|c|c|c|c|c|c|}
\hline Model & Unstandardized coefficients & Standardized coefficients & t & Sig. \\
\hline Constant & -8.812 & 6.638 & & -1.328 & .193 \\
\hline Lags (GDP,1) & 8.031 & 2.282 & 4.751 & 3.518 & .001 \\
\hline EXR & .058 & .025 & .731 & 2.283 & .029 \\
\hline INFL & .062 & .042 & .228 & 1.489 & .146 \\
\hline MS & 8.421 & 2.196 & 5.156 & 3.834 & .001 \\
\hline LIR & -.2601 & .125 & -.402 & -2.088 & .044 \\
\hline
\end{tabular}

a. Dependent variable: GDS

The Results of the OLS Regression Analysis are shown in table 2, 3, and 4 above. In table 2, Model Summary, the analysis Result produced statistics for coefficient of Determination $\left(\mathrm{R}^{2}\right)$ and Durbin-Watson (DW). Table 3, ANOVA, produced result for F-statistic and its significance. Table 4, coefficients, produced Result of the Beta for analyzing the level of contribution of each explanatory variable and the t-statistics for the significance of those contributions.

\subsection{Interpretation Of Results}

The results are interpreted in line with the research objectives. The coefficient of Determination $\left(\mathrm{R}^{2}\right)=$ .434 indicates that government deficit spending accounts for $43.4 \%$ of variations in explanatory variables under the study. That means that about $56.6 \%$ of other factors account for changes in the macroeconomic variables studied. The F-statistic. ( $\mathrm{F}$ value $=5.377$ ) however does not quite agree with the coefficient of determination $\left(\mathrm{R}^{2}\right)$ Result. With F-statistic at $53.77 \%$ and $\mathrm{R}^{2}$ at $43.4 \%$, there is a differential of almost $10 \%$. The value of Durbin-Watson statistic (2.061) shows that there is no autocorrelation in the model. Usually DW statistic value of approximately 2 indicates absence of autocorrelation. The results of the coefficient and t-statistic are used to evaluate the sub-objectives of the study. From the results of the coefficient, we explain the contribution and nature of the relationship between government deficit spending and the independent variables. The t-statistics give the results to test the hypotheses.

LnGDS $_{\mathrm{t}}=-8.812+8.031 \mathrm{LnGDP}_{\mathrm{t}-1}+.58 \mathrm{EXR}+.621 \mathrm{INFL}+8.421 \mathrm{LnMS}-2.60 \mathrm{LIR}$. Let us now look at the dependent variables, government deficit spending vis-a-vis the individual variables all of which are independent variables.

\section{Relationship Between Government Deficit Spending And Gdp}

The result of the coefficient $\left(8.031\right.$ LnGDP $\left._{-1}\right)$ shows that GDP lagged for 1 year has positive relationship with government deficit spending (GDS). That means that government deficit spending brings about growth in GDP in Nigeria. With t-statistic to GDP as 3.518 at .001 level of significance, there is indication that there is a significant positive relationship between GDP and GDS in Nigeria.

\section{Relationship Between Gds And Exr}

The standardized coefficient for Exchange Rate is .058 EXR. This shows that Exchange Rate (EXR) has positive relationship with Government Deficit Spending (GDS). This means that changes in GDS will cause EXR to change. The t-statistic is 2.283 with .029 level of significance and indicates a significant relationship between the two variables in Nigeria.

\section{Relationship Between Government Deficit Spending And Inflation In Nigeria}

The coefficient of the relationship between government deficit spending and inflation is .0621 INFL. This indicates that there is a positive relationship between inflation and GDS. This means that GDS causes inflation in Nigeria. With the value of t-statistic is 1.489 with .146 level of significance, at $5 \%$ level of significance GDS causes inflation in Nigeria.

\section{Relationship Between Gds And Money Supply (Ms)}

The result of the coefficient is 8.421 LnMS indicating that there is a positive relationship between GDS and MS. This means that increased GDS leads to increase in Money Supply. The t-statistic is 3.834 with .001 level of significance. At 5\% significance level, there is indication of significant positive relationship between government deficit spending and money supply. 


\section{Relationship Between Gds And Lending Interest Rate (Lir)}

The coefficient of lending interest rate to GDS is -.2604R. This implies a negative relationship between GDS and lending interest rate. That means increased GDS results to increase in interest rate.

\section{Summary Of Findings, Discussion, Conclusion And Recommendation}

In the relationship between Government Deficit Spending (GDP) and Economic Growth proxied by GDP, the finding is that a positive relationship exists between GDS and GDP. That means that increased deficit spending leads to economic growth. The result is constant with Keynesian theory of Aggregate Demand. These observations were also made by Anyanwu and Oaikhenan (1995). This implies the rejection of $\mathrm{H}_{01}$ that there is no significant relationship between GDS and GDP. The result is however inconsistent with the findings of Dalyop (2010) whose study shows that persistent government deficits in Nigeria have negative effects on GDP.

On the issue of Government Deficit Spending (GDS) and Exchange Rate (EXR) the study came up with the finding that there is positive significant relationship between GDS and EXR. This is consistent with the findings of Egwaikhide, Chete and Falokun (1994) whose study shows that domestic money supply, GDP and Exchange Rate are relevant in dealing with the causes of inflation in Nigerian. This means rejection of the Null Hypothesis $\left(\mathrm{H}_{04}\right)$.

When we consider the effects of GDS on Money Supply and Inflation in Nigeria, this study opines that Government Deficit Spending leads to increase in money supply and increases inflation. This is consistent with a priori expectations especially the views of monetarists that inflation is always and everywhere a monetary phenomenon caused by government. The finding is not, however consistent with the work of Omoke and Oruta (2010) whose finding is that government deficits do not cause inflation. Sill (2005) has same view that creation of money by seigniorage does not necessarily cause inflation. Onwioduokit (1999) confirms that government deficits cause inflation. Olusoji and Oderinde (2011) are inconclusive since their work could not determine whether it is fiscal deficits that cause inflation or vice versa.

On the question of effect of government deficits on lending interest rate, the study opines that there is a negative relationship between GDS and lending interest rate. The a priori expectation is that persistent deficits by government will raise lending rate and cost of funds. The effect is likely to crowd out the private sector. Obi and Abu (2009) have similar results in their study which also is confirmed by Ezeabasili and Mojekwu (2011) in their study.

\subsection{Conclusion}

Persisitent Government Deficit Spending has remained the unenviable hallmark of subsequent governments in Nigeria over the decades. They are believed to have adverse effects on most macroeconomic variables. The government needs to take certain steps to curtail the endless annual deficit financing.

\subsection{Recommendation}

The study came up with the opinion that the explanatory variables - GDP, Exchange Rate, Inflation, Money Supply and Lending Interest Rate - account for $43.4 \%$ of changes in the Government Deficit Spending. Further studies are recommended to explore other important variables such as Public Investment, Balance of Payments and endemic corruption. Aliyu and Elijah (2008) mentioned this endemic corruption as a factor that needs to be investigated.

\section{References}

[1] Atking F.W and Miller S.M (1985) The Relationship Between Government Deficit, Money Growth and Inflation, Journal of Macroeconomics 7(4) pp 447-467

[2] Aisen Ari and Hawner David (2008) Budget Deficits and Interest Rates: A Fresh Rerspective, IMF Working Paper WP/08/42

[3] Aliyu S.U.R and Elijah A.O (2008), Corruption and Economic Growth in Nigeria: 1986- 2007, MPRA Paper No 12504, http://wpra'ub.unimuenche.de.12504, retrieved 23/9/2009

[4] Anyanwu J.C and Oaikhenan H.E. (1995) Modern Macroeconomics: Theory and Application in Nigeria Onitsha, Joanee Educ. Publishers

[5] Asfaha S.G. (2007) National Revenue Funds: Their Efficacy for Fiscal Stability and /inter-government Equity Canada International /institute for Sustainable Development (IISD) retrieved 25/5/2012

[6] Blaug Mark (1998) Economic Theory in Retrospect, 5th ed. Cambridge, Cambridge University Press

[7] Burda Michael and Wyplosz Charles (1995) European Macroeconomics, and 2nd ed. Oxford University Press

[8] Cebula R.J (1995) The Impact of Federal Government Budget Deficits on Economic Growth in the US: An Empirical Investigation (1955-1992), InternationalReview of Economics and Finance 4(3) pp 245-252

[9] Dalyop T. Gadong (2010) Fiscal Deficits and the Growth of Domestic Out put in Nigeria, Jos Journal of Economics 4(1) pp 153-173

[10] Egwaikhide Festus O. Chete Louis N. and Falo Kuno Gabriel (1994) Exchange Rate Depreciation, Budget Deficit and inflation, the Nigerian Experience, OMIC Research Consortium, Research Paper 26. Pp 1-45

[11] Ezeabasili V.N., Mojekwu J.N. and Herbert E.W (2012), An Empirical Analysis of Fiscal Deficits and Inflation in Nigeria, CS Canada International Business and Management 4(1) pp. 105-120

[12] Ezeabasili V.N. and Mojekwu J.N. (2012), An Empirical Analysis of Fiscal Deficits and Interest Rate in Nigeria, Journal of Economics and International Finance Vol 3(4) pp 236-245 
[13] Ezeabasili V.N. and Ioraver N.T (2012) Economic Growth and Fiscal Deficits: Empirical Evidence from Nigeria, Economics and Finance Review 2(6) pp. 85-96

[14] Kanel Vit (2011) University of Economics, Prague, Czech Republic, google.com retrieved 23/5/2012

[15] Kustepeli Yesim- Yesim.Kustepeli@deu.edutr (retrieved 25/5/2012)

[16] Ludvigson S. (1996) The Macroeconomic Effects of Government Debt in a Stochastic Growth Model, Journal of Monetary Economics 38, pp 25-45

[17] Neaime S. (2008) Twin Deficits in Lebanon: A Time Series Analysis, IFE Lecture and Working Paper Series No 2 Beirut Institute of Financial Economics, American University of Beirut

[18] Nickel Christian and Vansteen Kitse (2008), Fiscal Policies, the Current Account and Ricardian Equivalence, European Central Bank working paper series NO. 935 September 2008

[19] Obi Ben and N. Abu (2009) Do Fiscal Deficits Raise Interest in Nigeria? A Vector Auto Regression (VAR) Approach, Journal of Applied Quantitative Methods 4(3)

[20] Odusola A.F and Akinlo A.E (no date) Output, Inflation and Exchange Rate In Developing Countries: An Application to Nigeria, the Developing Economics $\quad$ xxxix-2 pp.199-222

[21] Ogboru I. (2006), Macroeconomics, Kaduna, Liberty Pub, Ltd

[22] Okpanachi U.M and Abimiku C.A (2007) Fiscal Deficit and Macroeconomic Performance: A Survey of theory and Empirical Evidence- in Ogiji P.ed. The Nigerian Economy: Challenge and Directors for Growth in the Next 25 Years, Makudi, Aboki publishers

[23] Oladipo S.O and Akinbobola T.O (2011) Budget Deficit and Inflation in Nigeria Journal of Emerging Trends in Economics and Management Sciences, 2 (1) 1-8

[24] Olusiji M.O and Oderinde L.O (2011) Fiscal Deficit and Inflationary Trend in Nigeria: A Cross-casual Analysis, Journal of Economic Theory 5(2)

[25] Omoke Philip C. and Oruta Lawrence I. (2010) Budget Deficit, Money Supply and Inflation in Nigeria, European Journal of Economics, Finance and Administrative Sciences, Issue 19, http//www.eurojournals.com retrieved 23/3/2012

[26] Onwioduokit E.A. (1999) Fiscal Deficits and Inflation Dynamics in Nigeria: An Empirical Investigation of casual Relationship, CBN Economic and Financial Review Vol. 37(2) pp. 1-16

[27] Paiko I.I. (2012) Deficit Financing and its Implication on Private Sector Investment: The Nigerian Experience, Arabian Journal of Business and Management Review (OMAN) 1(9) pp.45-62.

[28] Sill Keith (2005) Do Budget Deficit Cause Inflation, Business Review Federal Reserve ～Bank of Philadelphia Q3 pp 26-33 